\title{
A Unique Cell Surface Antigen Identifying Lymphoid Malignancies of B Cell Origin
}

\author{
Lee M. Nadler, Jerome Ritz, Russell Hardy, John M. Pesando, and \\ Stuart F. Schlossman, Division of Tumor Immunology, Sidney Farber \\ Cancer Institute, Harvard Medical School, Boston, Massachusetts 02115 \\ Philip Stashenko, Department of Immunology, Forsyth Dental Center, Harvard \\ School of Dental Medicine, Boston, Massachusetts 02115
}

\begin{abstract}
A B S T R A C T A monoclonal antibody (anti-Bl) specific for a unique $B$ cell surface differentiation antigen was used to characterize the malignant cells from patients with leukemias or lymphomas. All tumor cells from patients with lymphomas or chronic lymphocytic leukemias, bearing either monoclonal $\kappa$ or $\lambda$ light chain, expressed the Bl antigen. In contrast, tumor cells from $\mathrm{T}$ cell leukemias and lymphomas or acute myeloblastic leukemias were unreactive. Approximately $50 \%$ of acute lymphoblastic leukemias (ALL) of non-T origin and $50 \%$ of chronic myelocytic leukemia in blast crisis were also anti-B1 reactive. Moreover, 21 of 28 patients with the common ALL antigen (CALLA) positive form of ALL were anti-B1 positive, whereas 0 of 13 patients with CALLA negative ALL were reactive.

These observations demonstrate that an antigen present on normal B cells is expressed on the vast majority of B cell lymphomas and on $\sim 75 \%$ of CALLA positive ALL, suggesting that these tumors may share a common B cell lineage.
\end{abstract}

\section{INTRODUCTION}

Leukemias and lymphomas, which were not previously distinguishable by either morphologic or histochemical criteria, can now be subdivided into clinically and pathologically distinct subgroups by use of a number of cell surface markers expressed on normal lymphocytes (1-3). For example, both normal and malignant B cells are defined by their expression of cell surface immunoglobulin $(4,5)$. Other markers of the B cell membrane, including receptors for the $\mathrm{Fc}$ portion of human

Dr. Nadler is a Research Fellow of the Medical Foundation, Inc., Boston, Mass. Dr. Pesando is a fellow of the Cancer Research Institute. Address reprint requests to Dr. Nadler.

Received for publication 4 August 1980 and in revised form 22 September 1980. immunoglobulin (6), receptors for components of the complement system (7), and HLA-D-related Ia-like antigens $(8,9)$ are less useful because they are not restricted to cells of $\mathrm{B}$ lineage and are also found on normal and malignant monocytes (10-12). In addition, Fc receptor-bound immunoglobin may give spuriously positive results for cell surface immunoglobulin (13). Although T cells have been shown to be reactive with anti-T cell antisera $(14,15)$, or to form erythrocyte rosettes with sheep erythrocytes (16), they, too, may express $\mathrm{F}_{\mathrm{C}}$ or $\mathrm{C} 3$ receptors or Ia-like antigens $(17-19)$. Finally, Null cells, which lack the conventional markers of $\mathrm{T}$ and $\mathrm{B}$ cells (20), also have been shown to express C3, Fc, or Ia-like antigens (21-23). Given the extent of overlap of many of these cell surface markers, considerable attention has been directed at defining unique cell surface antigens present on normal T, B, and Null cells, which can then be used to identify and classify leukemias and lymphomas.

In a recent study (24), we described the development and characterization of a monoclonal antibody (antiBl) that is reactive with a differentiation antigen expressed on all human B cells and on those cells destined to differentiate into immunoglobulin-secreting cells under pokeweed mitogen stimulation. The B1 antigen has been shown to be distinct from other known phenotypic markers of B cells, including surface immunoglobulin, $\mathrm{Fc}$ and $\mathrm{C} 3$ receptors, and Ia-like antigens. More importantly, anti-Bl was unreactive with normal T lymphocytes, Null cells, and granulocytes. In the present study, we have used anti-Bl to characterize a large number of malignancies thought to be of T, B, monocyte, myeloid, and Null cell origin. These studies demonstrate that anti-Bl reacts only with those B cell lymphomas that express either monoclonal $\kappa$ or $\lambda$ light chain. Of considerable interest is the demonstration that tumor cells from the majority of patients with the common acute lymphoblastic leukemia anti- 
gen (CALLA) ${ }^{1}$ positive non-T cell form of acute lymphoblastic leukemia (ALL) and chronic myelocytic leukemia $(\mathrm{CML})$ in blast crisis were also reactive with anti-Bl antibody. This study supports the notion that most $B$ cell lymphomas and many CALLA ${ }^{+}$ALL share a common $\mathrm{B}$ cell lineage.

\section{METHODS}

Patients and sample preparations. All patients in this study were evaluated at the Sidney Farber Cancer Institute, the Children's Hospital Medical Center, Peter Bent Brigham Hospital, Beth Israel Hospital, or the Massachusetts General Hospital. The diagnosis of lymphoma or leukemia was made using standard clinical, morphologic, and cytochemical criteria (25-27). Heparinized peripheral blood or bone marrow was collected from leukemic patients or from patients with circulating lymphomas (lymphosarcoma cell leukemias) before the administration of chemotherapeutic agents or blood products. Lymphocytes were separated from these specimens by Ficoll-Hypaque density gradient centrifugation, as previously described (28). Tumor masses and lymphoid tissue from patients with lymphomas were gently teased, minced into single cell suspensions, and passed through stainless steel mesh wire filters. Tumor cells were readily distinguishable from normal lymphocytes by Wright-Giemsa morphology, and all neoplastic preparations selected for this study had $>75 \%$ abnormal cells. Isolated tumor cells were studied either fresh or cryopreserved in $10 \%$ dimethyl sulfoxide and $20 \%$ fetal calf serum at $-196^{\circ} \mathrm{C}$ in the vapor phase of liquid nitrogen until the time of surface characterization.

Preparation of normal lymphocyte subpopulations. Human peripheral blood mononuclear cells were isolated from normal volunteer adult donors by Ficoll-Hypaque density gradient centrifugation. Normal lymphoid tissues from tonsil, lymph node, spleen, and thymus were prepared as described above. Unfractionated cells were then separated into B cell (surface immunoglobulin [sIg] positive), T cell (sheep erythrocyte rosette [E] positive), monocyte (adherent), and Null cell $\left(\mathrm{sIg}^{-}, \mathrm{E}^{-}\right)$by standard techniques (29). In particular, the B cell preparations were routinely $>90 \% \mathrm{sIg}^{+}$and $<5 \% \mathrm{E}^{+}$, nonreactive with anti-T cell antibodies, and $\sim 5 \%$ monocytes as judged by morphology, latex ingestion, and reactivity with the monocyte-reactive monoclonal antibody (M1) (30). The $\mathrm{T}$ cell populations obtained were $<2 \%$ $\mathrm{sIg}^{+}$and $>95 \% \mathrm{E}^{+}$, uniformly reactive with anti- $\mathrm{T}$ cell antibodies, and entirely negative with $\mathrm{M} 1$. Normal monocytes were obtained by adherence to plastic dishes as previously described (30), and were $95 \% \mathrm{Ml}^{+}$, but did not form erythrocyte rosettes, react with anti-T cell antisera, or express sIg. Null cells were $\mathbf{s I g}^{-}, \mathrm{E}^{-}$, and $\mathrm{T}$ cell antisera negative.

Cell surface markers. The cellular lineage of tumor cells was determined by a number of cell surface markers. The definition of $\mathrm{T}$ cell lineage was established by reactivity with a $T$ cell-specific heteroantiserum (14) and monoclonal antibodies (15), and by reactivity with sheep erythrocytes as previously described (16). All the T cell leukemias and lymphomas were $>75 \%$ reactive with the $\mathrm{T}$ cell-specific mono-

${ }^{1}$ Abbreviations used in this paper: ALL, acute lymphoblastic leukemia; CALLA, common acute lymphoblastic leukemia antigen; CLL, chronic lymphocytic leukemia; CML, chronic myelocytic leukemia; E, sheep erythrocyte rosette; G/M FITC, fluorescein-conjugated goat anti-mouse IgG; sIg, surface immunoglobulin. clonal antibodies and heteroantiserum, and these tumor cells were uniformly $>20 \%$ erythrocyte rosette reactive $(31,32)$.

The $B$ cell derivation of the tumor cell was demonstrated by the expression of either monoclonal $\kappa$ or $\lambda$ light chains on the tumor cell surface. Monoclonal antibodies specific for $\kappa$ or $\lambda$ light chain were used in all studies (provided by Dr. Victor Raso, Sidney Farber Cancer Institute, Boston, Mass.). In addition, a monoclonal antibody specific for the framework of the human HLA-D-related Ia-like antigen was used to analyze all normal and malignant cells for reactivity. The Ia-like antigens are gene products of the HLA-D region, which are present on the surface of normal peripheral blood B cells, a fraction of Null cells, monocytes, and activated T cells, but not on resting $\mathrm{T}$ cells (33). These Ia-like antigens have not been detected on the vast majority of $\mathrm{T}$ cell leukemias and lymphomas, but are expressed on most hematopoietic non-T cell malignancies. The anti-Ia antibody used in this study appears to be identical to the previously described heteroantiserum (19) and monoclonal antibodies (33), which identified a common framework expressed on all Ia-like antigens.

The non-T cell leukemias were characterized using a monoclonal antibody (J-5) (34), which has been shown to have the specificity of a previously described rabbit anti-CALLA antisera prepared in this laboratory (35).

The preparation and characterization of the anti-Bl antibody was the subject of a previous report (24). In brief, anti-Bl was developed by somatic cell hybridization, was cloned by limiting dilution, and has been passaged in ascites form in BALB/c mice for over $1 \mathrm{yr}$. Ascites form anti-Bl was used for all experiments. This antibody has been shown to be of the $\mathrm{IgG}_{2}$ subclass and can induce lysis of reactive cells with rabbit complement at dilutions up to 1:50,000. By indirect immunofluorescence, cytotoxicity, and quantitative absorption, the Bl antigen was present on $>95 \%$ of B cells from blood and lymphoid organs in all individuals tested. Monocytes, resting and activated $T$ cells, Null cells, myeloid cells, and $T$ cell lines were $B 1$ antigen negative. The $B l$ antigen was shown to be distinct from human immunoglobulin isotypes, Ia-like antigens, $F_{c}$ receptor of immunoglobulin, and the $\mathrm{C} 3$ receptor. Functional studies demonstrated that removal of the $\mathrm{B} 1$ antigen positive population from peripheral blood by cell sorting or complement-mediated lysis eliminated the cell population that is induced to differentiate into immunoglobulin-secreting plasma cells by pokeweed mitogen.

Indirect immunofluorescence analysis of normal and malignant cells with monoclonal antibodies. Normal or malignant cells were used fresh or thawed and washed extensively at the time of study; their viability exceeded $85 \%$ in all cases. In brief, $1-2 \times 10^{6}$ cells were treated with either 0.1 $\mathrm{ml}$ of a 1:500 dilution of the specific monoclonal antibody to be tested or $0.1 \mathrm{ml}$ of a 1:500 dilution of an unreactive control antibody of a similar immunoglobulin isotype, incubated at $4^{\circ} \mathrm{C}$ for $30 \mathrm{~min}$, and washed three times. These cells were reacted with $0.1 \mathrm{ml}$ of a $1: 40$ dilution of fluorescein-conjugated goat anti-mouse IgG (G/M FITC) (Meloy Laboratories, Inc., Springfield, Va.), incubated at $4^{\circ} \mathrm{C}$ for $30 \mathrm{~min}$, washed three times, and analyzed as previously described (36). Intensity of fluorescence was determined for 40,000 cells in each population on a fluorescence-activated cell sorter and compared with the fluorescence of a control nonreactive ascites. A displacement of the histogram of the test monoclonal antibody (Fig. 2A) was scored positive compared with the histogram of an unreactive isotype identical monoclonal antibody. In addition, for each test sample, a quantitative assessment of the number of positive cells was made (number of cells reactive with test monoclonal antibody minus number of cells reactive with the unreactive isotype identical monoclonal antibody divided by 40,000 total cells tested). Because the fluores- 


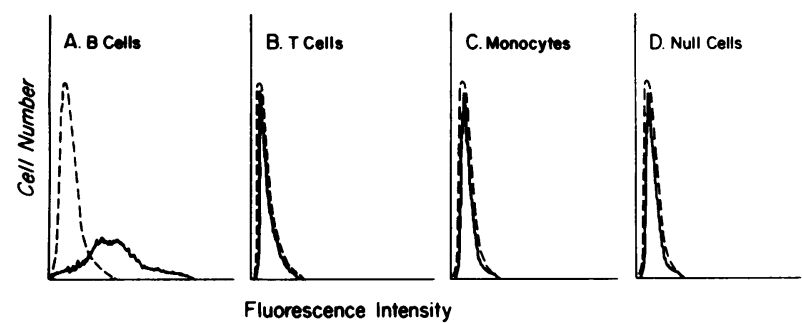

FIGURE 1 The fluorescence profile of fractionated B cells (A), $T$ cells (B), monocytes (C), and Null cells (D) with anti-Bl antibody and G/M FITC (solid line) is depicted in this figure. It is seen that B cells react with the anti-Bl antibody. Background fluorescence staining (dotted line) was obtained by incubating cells with an unreactive monoclonal antibody and developing with G/M FITC.

cence intensity of these antibodies was not different in dilutions from 1:50 to 1:10,000 or greater, it appeared that the intensity of reactivity related to the number of specific antigen-reactive determinants on the cell surface.

\section{RESULTS}

Distribution of $B 1$ antigen on normal hematopoietic tissues. As was previously shown (24), anti-B1 identified a surface antigen present on $\sim 9 \%$ of unfractionated peripheral blood mononuclear cells. Mononuclear cells from several individuals were separated into T, B, Null, and monocyte fractions and analyzed for reactivity using anti-Bl and G/M FITC. As shown in Fig. 1, the Bl antigen was found uniquely on B cells (Fig. 1A), and was absent from $T$ cells (Fig. 1B), monocytes (Fig. 1C), and Null cells (Fig. 1D). Moreover, the B1 antigen was present on the $\mathrm{Ig}^{+}$cells from tonsil $(64 \%$; $n=3)$, lymph node $(36 \% ; n=12)$, spleen $(35 \% ; n=8)$, and a small population of normal bone marrow (5\%; $n=5)$, but was not detected on thymocytes $(n=4)$. The intensity or amount of reactivity of these tissues with anti-B1 was similar to that found on peripheral blood B cells.

Reactivity of anti-B1 with malignant lymphomas. Anti-Bl was tested for reactivity with the tumor cells from patients with $B$ cell lymphomas. These tumors were determined to be of $B$ cell origin by the presence of cell surface monoclonal $\kappa$ or $\lambda$ light chains and by their failure to form erythrocyte rosettes or react with anti-T cell antisera. The tumors were classified according to the scheme of Rappaport (37) and included the following histologic types: $(a)$ diffuse, poorly differentiated lymphocytic $(n=18) ;(b)$ diffuse histiocytic ( $n$ $=7) ;(c)$ nodular, poorly differentiated lymphocytic $(n=8)$; $(d)$ Burkitt's lymphoma $(n=9) ;(e)$ nodular mixed $(n=3)$; $(f)$ Waldenstrom's $(n=2)$; and (g) myeloma $(n=3)$. In contrast to the patterns obtained with normal B cells, the reactivity of anti-B1 with these B cell tumors varied, and is illustrated in Fig. 2. For ex- ample, tumor cells from patients with chronic lymphocytic leukemia (CLL) were weakly but definitively reactive with anti-Bl (Fig. 2A). In contrast, the tumor cells from patients with nodular, poorly differentiated lymphocytic tumors (Fig. 2B) were moderately reactive, whereas the tumor cells from patients with Burkitt's lymphoma were strongly reactive (Fig. 2C). Of considerable interest was the finding that all plasma cell myelomas tested were unreactive (Fig. 2D). The results obtained with cells of 50 patients with B cell lymphoma are summarized in Table I. The tumor cells from all 47 patients with classical B cell lymphoma were reactive with anti-Bl, anti-Ia, and either anti- $\kappa$ or anti- $\lambda$ light chain, but not both. The three plasma cell myelomas tested were unreactive with anti-B1. The tumor cells from two of these patients lacked both the Ia antigen and surface $\kappa$ or $\lambda$; however, the tumor cells from the third patient expressed both. In contrast, only one of three patients with Null cell lymphoma was $\mathrm{Bl}^{+}$, although the tumor cells from all three of these patients were reactive with an anti-Ia antisera. Moreover, all 13

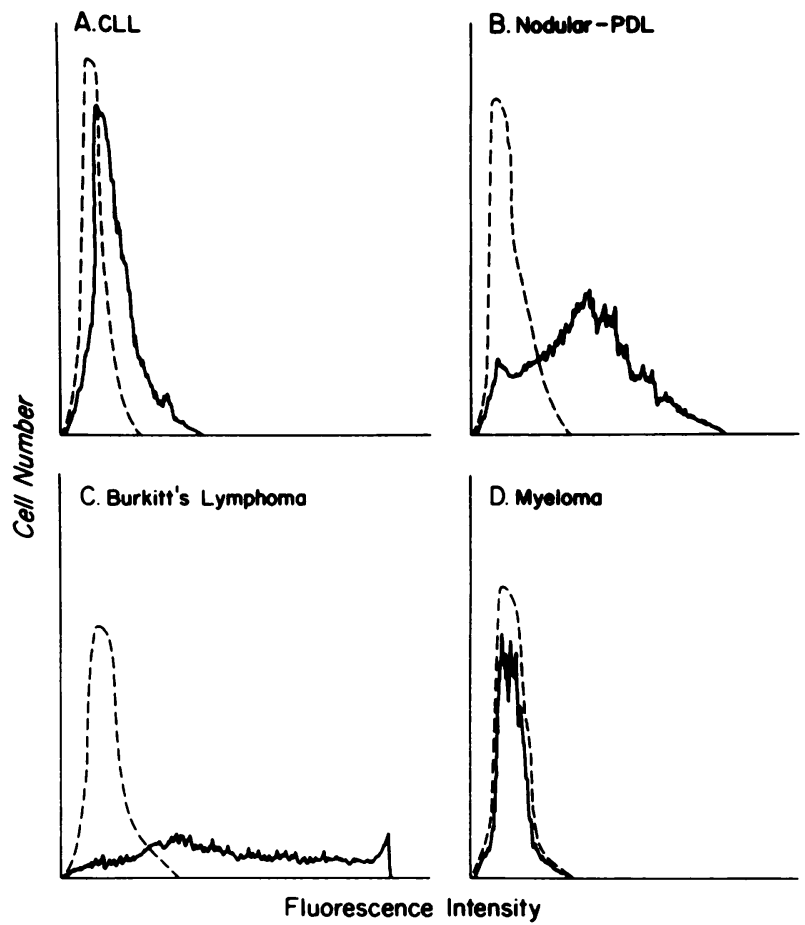

Figure 2 The fluorescence profile of tumor cells from patients with B cell CLL (A), nodular, poorly differentiated lymphocytic lymphoma (B), Burkitt's lymphoma (C), and plasma cell myeloma (D) with anti-B1 antibody and G/M FITC (solid line) is depicted in this figure. It can be seen that tumor cells from patients with CLL are weakly reactive, nodular, poorly differentiated lymphocytic cells are moderately reactive, Burkitt's lymphoma strongly reactive, and plasma cell myelomas are unreactive with anti-Bl. Background fluorescence staining was performed as in Fig. 1 . 
TABLE I

Reactivity of Lymphomas and Leukemias with Anti-B1

\begin{tabular}{|c|c|c|c|c|c|}
\hline \multirow[b]{2}{*}{ Tumor } & \multirow{2}{*}{$\begin{array}{l}\text { Number } \\
\text { of } \\
\text { patients }\end{array}$} & \multicolumn{4}{|c|}{ Number reactive with antisera } \\
\hline & & Ia & B1 & $\kappa$ or $\lambda$ & $\begin{array}{l}\text { Anti-T } \\
\text { cell }\end{array}$ \\
\hline \multicolumn{6}{|l|}{ Lymphomas } \\
\hline B cell & 50 & 48 & 47 & 48 & 0 \\
\hline Null cell & 3 & 3 & 1 & 0 & 0 \\
\hline $\mathrm{T}$ cell & 13 & 0 & 0 & 0 & 13 \\
\hline \multicolumn{6}{|l|}{ Leukemias } \\
\hline CLL & 18 & 18 & 18 & 18 & 0 \\
\hline ALL-non- T & 41 & 41 & 21 & 0 & 0 \\
\hline ALL-T cell & 17 & 0 & 0 & 0 & 17 \\
\hline CML_stable phase & 6 & 4 & 0 & 0 & 0 \\
\hline CML_blast crisis & 10 & 7 & 5 & 0 & 0 \\
\hline AML* & 16 & 15 & 0 & 0 & 0 \\
\hline
\end{tabular}

*AML, acute myeloblastic leukemia.

T cell lymphomas tested were unreactive with antiIa, anti-Bl and anti- $\kappa$ or anti- $\lambda$ monoclonal antibodies.

Reactivity of anti-B1 with leukemias. Since the vast majority of sIg-bearing (B cell) lymphomas were reactive with anti-B1, we next evaluated the expression of the Bl antigen on leukemic cells. As can be seen in Table I, the tumor cells from patients with CLL expressed monoclonal surface $\kappa$ or $\lambda$ light chain, Ia antigen, and Bl antigen. An unexpected result was noted when the ALL cells were tested with anti-Bl. It was found that the tumor cells from $\sim 50 \%$ of the patients with non-T cell ALL were $\mathrm{Bl}^{+}$. Leukemic cells from these individuals lacked surface $\kappa$ or $\lambda$, but were $\mathrm{Bl}^{+}$ and $\mathrm{Ia}^{+}$. T cell ALL were unreactive with anti-Bl and anti-Ia. In contrast, tumor cells from patients with acute myeloblastic leukemia were generally $\mathrm{Ia}^{+}$and uniformly lacked the $\mathrm{Bl}$ antigen. These findings provided additional support for the view that the anti-Bl was unreactive with conventional sIg or Ia-like antigens. In addition, it was found that 5 of 10 patients with CML in blast crisis were $\mathrm{Bl}^{+}$, whereas 0 of 6 patients with stable phase CML were unreactive with anti-B1.

Coexpression of $B 1$ antigen and CALLA on non-T cell leukemias. Given the reactivity of anti-B1 with some, but not all, non-T cell ALL, the relationship of the B1 antigen to CALLA was then investigated. Previous studies have shown that CALLA is a tumor-associated antigen expressed on the leukemic cells from $80 \%$ of

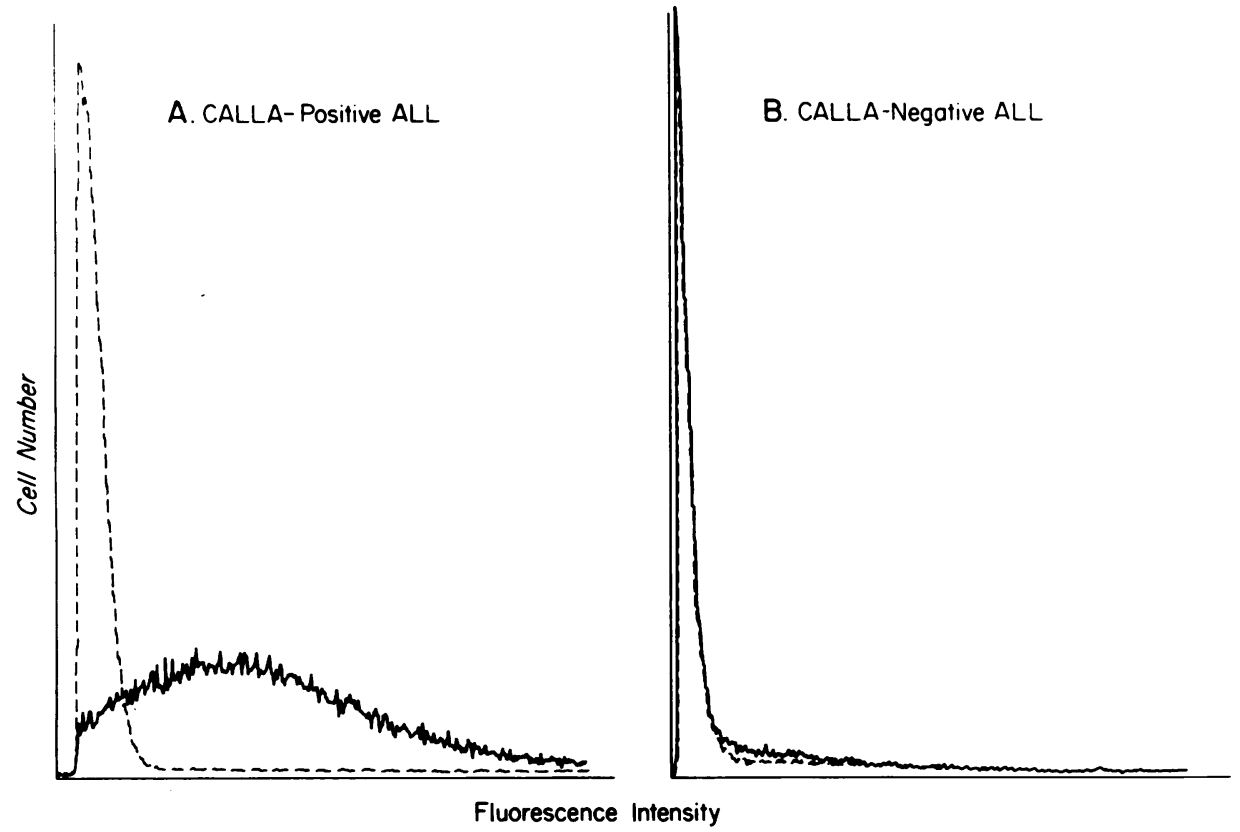

FIGURE 3 The fluorescence profile of the tumor cells from a patient with a CALLA ${ }^{+}$ALL (A) and CALLA ${ }^{-}$ALL (B) with anti-B1 antibody and G/M FITC (solid line) is depicted in this figure. It can be seen that the tumor cells from the CALLA ${ }^{+}$ALL were uniformly reactive with antiBl (A), whereas the tumor cells from the CALLA $^{-}$patient were unreactive (B). Background fluorescence staining was performed as in Fig. l. The tumor cells from approximately one-third of patients with CALLA ${ }^{+}$ALL had an identical fluorescence pattern to the one depicted in Fig. 3A. The fluorescence intensity patterns of the two-thirds of patients with CALLA ${ }^{+}$ALL were equally divided between weak expression (similar to Fig. 2A) and moderate expression (similar to Fig. 2B). 
TABLE II

Reactivity of Anti-B1 with CALLA Positive and Negative Leukemic Cells

\begin{tabular}{lcrrr}
\hline \multicolumn{1}{c}{ Tumor } & $\begin{array}{c}\text { Number of } \\
\text { patients }\end{array}$ & \multicolumn{2}{c}{$\begin{array}{c}\text { Number } \\
\text { reactive } \\
\text { with antisera }\end{array}$} \\
\cline { 3 - 5 } & 28 & 28 & Ia & B1 \\
\hline Non-T cell ALL, CALLA & & & 21 \\
Non-T cell ALL, CALLA & & 13 & 13 & 0 \\
CML_blast crisis, CALLA & 7 & 6 & 5 \\
CML_blast crisis, CALLA & & 3 & 1 & 0
\end{tabular}

patients with non-T cell ALL and $\sim 30 \%$ of patients with CML in blast crisis (38). This antigen has been shown to be a glycoprotein with a molecular mass of 100,000 daltons. Recently, a monoclonal antibody (J-5), specific for CALLA, has been described. The tumor cells from 41 patients with non-T ALL and 10 patients with CML in blast crisis were then compared for their reactivity with anti-Ia, anti-CALLA, and anti-B1 monoclonal antibodies. The reactivity of anti-Bl with the tumor cells from a CALLA positive and a CALLA negative patient is depicted in Fig. 3. Fig. 3A shows that the tumor cells from a patient with $\mathrm{CALLA}^{+}$ALL were reactive with the anti-Bl antibody, whereas Fig. 3B shows that the tumor cells from a patient with CALLA ${ }^{-}$ ALL were unreactive. Further heterogeneity of the CALLA $^{+}$ALL and CML in blast crisis could be demonstrated by their reactivity with anti-Bl. As shown in Table II, the tumor cells from 21 of 28 patients with $\mathrm{CALLA}^{+}, \mathrm{Ia}^{+} \mathrm{ALL}$ were reactive with anti-Bl. In contrast, no tumor cells from the 13 patients with CALLA', $\mathrm{Ia}^{+}$ALL were reactive. Similarly, most of the CALLA ${ }^{+}$, $\mathrm{Ia}^{+} \mathrm{CML}$ in blast crisis were anti-B1 reactive; and all of the CALLA ${ }^{-}, \mathrm{Ia}^{+} \mathrm{CML}$ in blast crisis were unreactive.

\section{DISCUSSION}

In the present study, we have used a monoclonal antibody previously shown to be specific for a B cell surface-differentiation antigen to characterize malignant cells from patients with leukemias and lymphomas of various cellular origins. Examinations of the nonHodgkin's lymphomas with classical cell surface markers demonstrated that $\sim 80 \%$ of these tumors and $>95 \%$ of CLL are of B cell lineage (3). Morphologically, the B cell lymphomas are heterogeneous, and the observed histologic diversity has led to the development of several classification schemes (37-40). These B cell tumors have also been shown to be variable in their amount of expression of surface or intracytoplasmic immunoglobulin, complement receptors, formation of monkey erythrocyte rosettes, $\mathrm{Fc}$ receptors, and Ia-like antigens. It has therefore been postulated that the cell surface marker and histologic diversity seen in these tumors may reflect distinct stages of B cell differentiation in which the malignant cells are "frozen" (41). Unfortunately, the various cell surface markers presently used define neither unique histologic subtypes nor distinct clinical subgroups. Nevertheless, given the better prognosis of B cell neoplasms compared with $\mathrm{T}$ or Null cell tumors, a number of these markers have been widely used $(42,43)$.

In this study, the tumor cells from all 18 patients with B cell CLL and 47 of 50 patients with B lymphomas, all bearing $\kappa$ or $\lambda$ light chains, were reactive with the anti-Bl antibody. Moreover, anti-Bl was unreactive with acute $T$ cell leukemias and lymphomas and with tumor cells from all patients with acute myeloblastic leukemia. These observations suggest that anti-Bl adds to the repertoire of cell surface determinants that define B cell tumors, and unlike Ia, Fc, and C 3 , it is restricted to this class of cells. More importantly, the presence of $\mathrm{Bl}$ antigen in conjunction with the expression of monoclonal $\kappa$ or $\lambda$ light chains provides additional criteria for the definition of a malignant $B$ cell clone. In this regard, normal B cells and other cells capable of binding immunoglobulin via an $F_{c}$ receptor are invariably heterogeneous with regard to their light chain phenotype, and as such, can be distinguished from B cell neoplasms.

Although anti-Bl was reactive with the vast majority of B cell lymphomas and all B cell CLL, the non-T cell ALL were divided into several distinct entities. These tumor cells have been shown to be unreactive with anti-T and anti-Ig reagents, but to be strongly reactive with anti-Ia and anti-CALLA. Previous studies have shown that $95 \%$ of non-T cell ALL are $\mathrm{Ia}^{+}$, whereas CALLA was coexpressed on $\sim 80 \%$ of the non-T cell ALL. These studies indicated that the majority of non- $T$ cell $\mathrm{ALL}$ were $\mathrm{CALLA}^{+}, \mathrm{Ia}^{+}$, and a small group were CALLA $^{-}, \mathrm{Ia}^{+}$. Little is known about the small subset of patients $(1-2 \%)$ who express cell surface immunoglobulin and are therefore thought to represent a more mature B cell ALL.

The present studies have shown that the tumor cells from $\sim 50 \%$ of patients with non-T cell ALL were reactive with anti-Bl. More importantly, most of the $\mathrm{CALLA}^{+}, \mathrm{Ia}^{+}$ALL were anti-Bl reactive, whereas all of the CALLA ${ }^{-}, \mathrm{Ia}^{+}$ALL were anti-Bl unreactive. Thus, the non- $T$ cell ALL can now be divided into three major subclasses: (a) $\mathrm{CALLA}^{+}, \mathrm{Ia}^{+}, \mathrm{Bl}^{+}$; (b) $\mathrm{CALLA}^{+}$, $\mathrm{Ia}^{+}, \mathrm{Bl}^{-}$; and (c) CALLA' $\mathrm{Ia}^{+}, \mathrm{Bl}^{-}$. These studies provide additional support for the view that a significant fraction of $\mathrm{CALLA}^{+}$ALL was B cell derived. Other investigators have demonstrated that $\sim 20-30 \%$ of CALLA $^{+}$ALL had the characteristics of pre-B cells in that they contained intracytoplasmic $\mu$ chain and lacked both surface and cytoplasmic light chains (44-46). The present study would suggest that, in fact, the majority 
of $\mathrm{CALLA}^{+}, \mathrm{Ia}^{+} \mathrm{ALL}$ are B cell derived, since $75 \%$ were anti-B1 ${ }^{+}$. Whether $\mathrm{Bl}$ is expressed earlier than cytoplasmic immunoglobulin in B cell differentiation, or is a more sensitive marker of pre-B cells, is yet to be resolved.

The demonstration that the Bl antigen is expressed on all normal B cells, B cell lymphomas, and a proportion of acute leukemias suggests that the $B 1$ antigen is expressed on most stages of $B$ cell differentiation. It was intriguing to find that the generally accepted endstage cell in B cell ontogeny, the plasma cell, lacked B1. Thus, Bl appears to be a B cell differentiation antigen present throughout most stages of $B$ cell maturation. Similarly, a number of anti-T cell antibodies have been described that are capable of dissecting normal intraand extrathymic maturation (47), as well as defining distinct subsets of clinically relevant malignant $T$ cell leukemias and lymphomas $(31,32,38,48,49)$.

Because monoclonal antibodies are of extremely high titer and can be produced in unlimited quantities compared with heteroantisera, the utility of this marker can now be readily adopted by many laboratories studying B cell tumors. Additional B cell-specific antibodies will be required for the dissection of distinct stages of $B$ cell differentiation and for the identification of clinically relevant subgroups of B cell lymphoproliferative malignancies.

\section{ACKNOWLEDGMENTS}

The authors would like to thank the members of the Divisions of Hematology, Oncology, Pathology, and Surgery of the Sidney Farber Cancer Institute, the Peter Bent Brigham Hospital, the Beth Israel Hospital, the Children's Hospital Medical Center, and the Massachusetts General Hospital for help in obtaining tissue specimens. We would also like to thank Dr. Alan C. Aisenberg for his encouragement and helpful discussions. We would also like to thank Mr. John Daley for technical assistance, and Ms. Luci M. Grappi for excellent secretarial assistance during the preparation of this manuscript.

This work was supported by National Institutes of Health grants AI 12069, CA 19589, CA 06516, RR 05526, and DE 04881 .

\section{REFERENCES}

1. Siegal, F. P. 1978. Cytoidentity of the lymphoreticular neoplasms. In The Immunopathology of Lymphoreticular Neoplasms. J. J. Twomey and R. A. Good, editors. Plenum Medical Book Company, New York. 281-324.

2. Brouet, J. C., and M. Seligmann. 1978. The immunological classification of acute lymphoblastic leukemias. Cancer. 42: 817-827.

3. Mann, R. B., E. S. Jaffe, and C. W. Berard. 1979. Malignant lymphomas - a conceptual understanding of morphologic diversity. Am. J. Pathol. 94: 104-191.

4. Froland, S., J. B. Natvig, and P. Berdal. 1971. Surfacebound immunoglobulin as a marker of $B$ lymphocytes in man. Nature (Lond.). 234: 251-252.

5. Aisenberg, A. C., and K. J. Bloch. 1972. Immunoglobulins on the surface of neoplastic lymphocytes. N. Engl. J. Med. 287: 272-276.

6. Dickler, H. B., and H. G. Kunkel. 1972. Interaction of the aggregated $\gamma$-globulin with B lymphocytes. J. Exp. Med. 136: $191-196$.

7. Bianco, C., R. Patrick, and V. Nussenzweig. 1970. A population of lymphocytes bearing a membrane receptor for antigen-antibody complement complexes. J. Exp. Med. 132: 702-720.

8. Winchester, R. J., S. M. Fu, P. Wernet, H. G. Kunkel, B. Dupont, and C. Jersild. 1975. Recognition by pregnancy serum of non-HLA allo-antigen selectively expressed on B lymphocytes. J. Exp. Med. 141: 924-929.

9. Schlossman, S. F., L. Chess, R. E. Humphreys, and J. L. Strominger. 1976. Distribution of Ia-like molecules on the surface of normal and leukemic human cells. Proc. Natl. Acad. Sci. U. S. A. 73: 1288-1292.

10. Huber, H., S. D. Douglas, and H. H. Fudenberg, 1969. The IgG receptor: an immunological marker for the characterization of mononuclear cells. Immunology. 17:7-21.

11. Preud'homme, J. L., and G. Flandrin. 1974. Identification of peroxidase staining of monocytes in surface immunofluorescence tests. J. Immunol. 113: 1650-1653.

12. Jaffe, E. S., E. M. Shevach, E. H. Sussman, M. Frank, I. Green, and C. W. Berard. 1975. Membrane receptor sites for the identification of lymphoreticular cells in benign and malignant conditions. Br. J. Cancer. 31(Suppl. 2): $107-120$.

13. Winchester, R. J., S. M. Fu, and H. G. Kunkel. 1975. IgG on lymphocyte surfaces: technical problems and the significance of a third cell population. J. Immunol. 114: 1210-1212.

14. Pratt, D. M., S. F. Schlossman, and J. L. Strominger. 1980. Human T lymphocyte surface antigens: partial purification and characterization utilizing a high-titer heteroantiserum. J. Immunol. 124: 1449-1461.

15. Reinherz, E. L., and S. F. Schlossman. 1980. The differentiation and function of human $\mathrm{T}$ lymphocytes: a review. Cell. 19: 821-827.

16. Mendes, N. F., M. C. A. Tolnai, N. P. A. Silveira, R. B. Gilbertsen, and R. S. Metzgar. 1973. Technical aspects of the rosette tests used to detect human complement receptors and sheep erythrocyte binding. J. Immunol. 111: 860-867.

17. Ross, G. D., E. M. Rabellino, M. C. Polley, and H. M. Grey. 1973. Continued studies of complement receptor and surface immunoglobulin-bearing cells and sheep erythrocyte rosette-forming cells in normal and leukemic human lymphocytes. J. Clin. Invest. 52: 377-385.

18. Moretta, L., M. Ferrarini, M. C. Mingari, A. Moretta, and S. R. Webb. 1977. Subpopulations of human T cells identified by receptors for immunoglobulins and mitogen responsiveness. J. Immunol. 117: 2171-2174.

19. Evans, R. L., T. J. Faldetta, R. E. Humphreys, D. M. Pratt, E. J. Yunis, and S. F. Schlossman. 1977. Peripheral human $T$ cells sensitized in mixed leukocyte culture synthesize and express Ia-like antigens. J. Exp. Med. 148: 1440-1445.

20. MacDermott, R. P., L. Chess, and S. F. Schlossman. 1975 Immunologic functions of isolated human lymphocyte subpopulations. V. Isolation and functional analysis of a surface Ig negative, $\mathrm{E}$ rosette negative subset. Clin. Immunol. Immunopathol. 4: 415-424.

21. Chess, L., H. Levine, R. P. MacDermott, and S. F. Schlossman. 1975. Immunologic functions of isolated human lymphocyte subpopulations. VI. Further characterization of the surface of Ig negative, $E$ rosette negative (Null cell) subset. J. Immunol. 115: 1483-1487.

22. Chess, L., and S. F. Schlossman. 1977. Human lympho- 
cyte subpopulations. In Advances in Immunology. F. J. Dixon and H. G. Kunkel, editors. Academic Press, Inc., New York. 213-247.

23. Chess, L., R. L. Evans, R. E. Humphreys, J. L. Strominger, and S. F. Schlossman. 1976. Inhibition of antibodydependent cellular cytotoxicity and immunoglobulin synthesis by an antiserum prepared against a human B-cell Ialike molecule. J. Exp. Med. 144: 113-122.

24. Stashenko, P., L. M. Nadler, R. Hardy, and S. F. Schlossman. 1980. Characterization of a human B lymphocyte specific antigen. J. Immunol. 125: 1678-1685.

25. Bennett, J. M., D. Catovsky, M. T. Daniel, G. Flandrin, D. A. G. Galton, H. R. Gralnick, and C. Sultan. 1976. Proposals for the classification of the acute leukemias. $\mathrm{Br}$. J. Haematol. 33: 451-458.

26. Hayhoe, F. G. J., M. Quagliano, and R. Doll. 1964. The Cytology and Cytochemistry of Acute Leukemias: A Study of 140 Cases. Her Majesty's Stationery Office, London.

27. Hayhoe, F. G. J., and R. J. Flemans. 1970. An Atlas of Haematological Cytology. Wiley-Interscience, New York. 110-265.

28. Boyum, A. 1968. Separation of leucocytes from blood and bone marrow. Scand. J. Clin. Lab. Invest. 21(Suppl. 97): 51-76.

29. Chess, L., and S. F. Schlossman. 1976. Antiimmunoglobulin column and the separation of T, B, and Null cells. In In Vitro Methods in Cell-Mediated and Tumor Immunity. Academic Press, Inc., New York. 255-261.

30. Breard, J., E. L. Reinherz, P. C. Kung, G. Goldstein, and S. F. Schlossman. 1980. A monoclonal antibody reactive with human peripheral blood monocytes. J. Immunol. 124: 1943-1948.

31. Reinherz, E. L., L. M. Nadler, S. E. Sallan, and S. F. Schlossman. 1979. Subset derivation of $T$ cell acute lymphoblastic leukemia in man. J. Clin. Invest. 64: 392397.

32. Reinherz, E. L., P. C. Kung, G. Goldstein, R. H. Levey, and S. F. Schlossman. 1980. Discrete stages of human intrathymic differentiation: analysis of normal thymocytes and leukemic lymphoblasts of T lineage.Proc. Natl. Acad. Sci. U. S. A. 77: 1588-1592.

33. Reinherz, E. L., P. C. Kung, J. M. Pesando, J. Ritz, G. Goldstein, and S. F. Schlossman. 1979. Ia determinants on human $\mathrm{T}$ cell subsets defined by monoclonal antibody: activation stimuli required for expression. J. Exp. Med. 150: $1472-1482$.

34. Ritz, J., J. M. Pesando, J. Notis-McConarty, H. Lazarus, and S. F. Schlossman. 1980. A monoclonal antibody to human acute lymphoblastic leukemia antigen. Nature (Lond.). 283: 583-585.
35. Pesando, J. M., J. Ritz, H. Lazarus, S. B. Costello, S. E. Sallan, and S. F. Schlossman. 1979. Leukemia-associated antigens in ALL. Blood. 54: 1240-1248.

36. Nadler, L. M., P. Stashenko, R. Hardy, and S. F. Schlossman. 1980. A monoclonal antibody defining a lymphomaassociated antigen in man. J. Immunol. 125: 570-577.

37. Rappaport, H. 1966. Tumors of the hematopoietic system. In Atlas of Tumor Pathology, Section 3, Fascicle 9. Armed Forces Institute of Pathology, Washington, D. C. 13.

38. Greaves, M. F., G. Brown, N. T. Rapson, T. A. Lister. 1975. Antisera to acute lymphoblastic leukemia cells. Clin. Immunol. Immunopathol. 4: 67-84.

39. Braylan, R. C., E. S. Jaffe, and C. W. Berard. 1975. Malignant lymphomas: current classification and new observations. Pathol. Annu. 10: 213-270.

40. Dorfman, R. F. 1977. Pathology of the non-Hodgkin's lymphomas: new classifications. Cancer Treat. Rep. 61: 945-952.

41. Salmon, S. E., and M. Seligmann. 1974. B-cell neoplasia in man. Lancet. II: 1230-1233.

42. Bloomfield, C. D., J. H. Kersey, R. D. Brunning, and K. J. Gajl-Peczalska. 1976. Prognostic significance of lymphocyte surface markers in adult non-Hodgkin's malignant lymphoma. Lancet. II: 1330-3.

43. Bloomfield, C. D., K. J. Gajl-Peczalska, G. Frizzem, J. H. Kersey, and A. I. Goldman. 1979. Clinical utility of lymphocyte surface marker combined with the LukesCollins histologic classification in adult lymphoma. $N$. Engl. J. Med. 301: 512-578.

44. Vogler, L. B., W. M. Crist, D. E. Bockman, E. R. Pearl, A. R. Lawton, and M. D. Cooper. 1978. Pre-B cell leukemia: a new phenotype of childhood lymphoblastic leukemia. N. Engl. J. Med. 298: 872-878.

45. Brouet, J. C., J. L. Preud'homme, C. Penit, F. Valensi, P. Rouget, and M. Seligmann. 1979. Acute lymphoblastic leukemia with pre-B cell characteristics. Blood. 54: 269-273.

46. Greaves, M. F., W. Verbi, L. B. Vogler, M. Cooper, R. Ellis, K. Ganeshguru, V. Hoffbrand, G. Janossy, and F. J. Bollum. 1979. Antigenic and enzymatic phenotypes of the pre-B subclass of acute lymphoblastic leukemia. Leuk. Res. 3: 353-362.

47. Reinherz, E. L., and S. F. Schlossman. The derivation of human $\mathrm{T}$ cell malignancies. Cancer Treat. Rep. In press.

48. Nadler, L. M., E. L. Reinherz, H. J. Weinstein, C. J. D'Orsi, and S. F. Schlossman. 1980. Heterogeneity of T cell lymphoblastic malignancies. Blood. 55: 806-810.

49. Nadler, L. M., E. L. Reinherz, and S. F. Schlossman. 1980. The $\mathrm{T}$ lymphoblastic malignancies: a review. Cancer Chemother. Pharmacol. 4: 11-15. 